\title{
Empire, Philanthropy, Public Diplomacy
}

The "American question" provoked a staggering variety of meanings for embattled radicals and emboldened aristocrats across the Old World. ${ }^{1}$ As Don Doyle has recently described it, contemporary Europeans viewed the conflict as "a decisive showdown between the forces of popular versus hereditary sovereignty, democracy versus aristocracy, free versus slave labor, all rolled into one grand epic battle taking place in the distant American arena." In the British case, the idea of a "grand epic battle" between the forces of progress and reaction has proven especially appealing because it reflects the furious domestic battles over parliamentary reform that animated the nation throughout the I860s. "You are fighting the battle of liberalism in Europe as well as the battle of freedom in America," the English liberal Richard Cobden assured the radical Republican Charles Sumner in January I $865 .{ }^{3}$ Union and Confederate propagandists appealed to a global audience through the conceptual currents of liberalism, nationalism, and race that crisscrossed the Atlantic in the mid-nineteenth century. In the process of defining nationhood and nationality and of mobilizing domestic economies to fulfill the demands of industrial warfare, Northerners and Southerners not only turned to analogous global events but attempted to illustrate how effectively interwoven their respective sections were within the global economy. ${ }^{4}$

An unintended consequence of historians' focus on the ideological conflict between democracy and aristocracy has been the neglect of one of the central optics through which British commentators and Americans 
overseas framed the war's meaning: empire. ${ }^{5}$ British political historians have recently shifted focus from the class-defined meanings of the Victorian nation that have preoccupied historians of Civil War foreign relations to the intersections of nation, empire, race, and anti-slavery. ${ }^{6}$ For outward-looking Northerners and Southerners alike, situating the Civil War within the context of the expanding power and scope of British imperialism and domestic debates over imperial policy came naturally. Although divided over how best to harness British imperial power to their own ends, Confederates and Unionists overseas were forthcoming about the supposed convergence of interests between their respective governments and British imperial self-interest. Emigrant diplomats engaged closely with the post-emancipation dilemmas of Britain's supposedly antislavery empire and embraced the racial hierarchies that buttressed British imperialism. This chapter places Union and Confederate public diplomacy into this imperial framework.

Pro-Union Americans in Britain relied on the London American for their diplomatic voice. The American's editors, John Adams Knight and A. W. Bostwick, quickly rallied behind the Union cause, blamed the war on Southern intransigence, and reported the lecture campaign of its owner, George Francis Train. Train's propaganda mixed radical Young American republicanism with appeals to shared Anglo-Saxon superiority over the world's "uncivilized" inhabitants. Through appeals to imperial identity, Union and Confederate diplomacy forged unexpected affinities. Confederate agitation was coordinated by Henry Hotze through his now well-known propaganda journal The Index, whose offices on Fleet Street were just two doors down from the American's. ${ }^{7}$ Hotze and his fellow propagandists portrayed Southern slavery as the economic engine of the global economy and simultaneously attempted to spread American racial "science" amongst European race theorists. The ideas of Train and Hotze intersected in these intellectual circles that anticipated transimperial race-making in the late nineteenth century.

In the war's final year, transnational currents of humanitarianism shaped Union diplomacy. Managed by the energetic Edmund Crisp Fisher, the United States Sanitary Commission's London Branch brought new verve to Union diplomatic strategy. Fisher distributed Sanitary Commission literature through American networks in Britain and channeled financial and material support for the Union from Americans overseas. The London Branch's mission is emblematic of the emergence of new transnational networks whose lineage can be directly linked to the global impact of the US Civil War. Fisher's London Branch had roots in Britain's 
American community and subsequently forged new intellectual connections between humanitarian movements on both sides of the Atlantic. For their own part, Fisher and his allies found that the longstanding associational and civic life of the London-Americans and Britain's network of charitable and reform organizations were the ideal vehicle for mobilizing British moral suasion behind the Union cause. The Sanitary Commission's humanitarian impulse therefore looked forward to the emergence of international society in the early twentieth century, but despite its progressive orientation was equally entwined with the Anglo-Saxon mythologizing increasingly central to Anglo-American relations.

\section{EMPIRE AND RACE IN CIVIL WAR FOREIGN RELATIONS}

In the war's early months, George Francis Train was the most vocal Union propagandist in Great Britain. Train first arrived in Britain in the fall of I 850 to undertake his commercial apprenticeship with the White Diamond Line of Enoch Train \& Co. (owned by his father's cousin), a Boston-Liverpool packet line shipping Staffordshire crockery, iron and steel, and various other dry goods. ${ }^{8}$ The Bostonian then had a varied and impulsive career touring the globe as a partner in Caldwell, Train \& Co. He returned to Britain once more in $\mathrm{I} 858$ as a promoter of street railways in Liverpool, Birkenhead, and London. With the outbreak of the Civil War, Train reinvented himself again as the Union's chief booster. The self-proclaimed prophet of "Spread-Eagle" American nationalism entertained tenaciously throughout London, hosting dinners and banquets marked by spontaneous renditions of "De Camptown Races" with improvised verses. ${ }^{9}$

Train brought persistence and urgency to the Union's public diplomacy in Britain. Between January I86I and March I862, Train made twenty-three major public addresses in addition to hosting countless breakfasts and lunches, often on days of US national celebration, and writing numerous articles for the London American. ${ }^{10}$ Under Train's influence, the American exhorted emigrants into activity. "If there ever was a time when Americans residing abroad should express their patriotism, that time is now," the American implored. ${ }^{11}$ Disdaining the moral treachery of neutrality, Train chided his audience, "sojourn abroad does not destroy patriotism." 12 Through the American he scolded prominent emigrant bankers for "waiting for victories before hoisting the Secession or Union Flags." ${ }^{13}$ Train's speeches praised the United States' revolutionary past and commitment to political liberty, but he was more interested 
in shocking his audiences than persuading them and could barely disguise his habitual Anglophobia. In June I86I, Train hosted a pro-Union banquet at the Westminster Palace Hotel in commemoration of the Battle of Bunker Hill. Like Peabody's Fourth of July celebrations, Train's guest list was designed to maximize the public diplomacy of the occasion. More than a dozen prominent British newspaper editors were present alongside the authors George Augustus Sala and Thomas Colley Grattan; the publisher George Routledge; and Paul Julius Reuter, founder of Reuter's Telegram Company. The dinner, Train told the assembled company, was convened "in the hope of counteracting the evil effects of those secession journalists and statesmen who cheer so loudly whenever the 'bursting of the republican bubble' is alluded to." 14

Train appealed directly to Britain's self-conception as an anti-slavery empire. Britain, he claimed, "must acknowledge that the republic is a success, or keep on as she has done, siding with the rebels." "We must hang some new pictures on the wall," he taunted, of "abolitionist England sitting affectionately in the lap of negro slavery." Train repeatedly linked the Civil War to America's ongoing struggle to consolidate the legacy of the American Revolution, arguing that sectional strife was the culmination of the revolutionary process. "Our revolution is a war of ideas-a war of freedom—a war for oppressed mankind," he told an audience in May I862, contrasting it with the policy of Britain whose "idea of liberty is freedom for England and slavery for all mankind." 15 "Thank God, America is emancipated from England," he told an audience in June, "and intends now to turn the tables and patronize England as England has formerly patronized America." 16

By strategically manipulating the Irish Question, Train's English tour became a platform to prove his credentials as a pro-Union Democrat committed to the revolutions of I 848 . Speaking at a meeting of the Irish Brotherhood of St Patrick in London in August I862, Train distilled his Anglophobia into a prediction of England's impending downfall. According to Train, in the ideological battle between empire and selfdetermination "the American rebellion is the world's rebellion, and the life of America is the death of England." ${ }^{17}$ Outlining a fanciful system to decolonize Britain's white settler colonies of Canada and Australia, Train told the assembled Irishmen that "The downfall of England is rapid ... when its extremities decay." 18 Should Irishmen overcome sectarian prejudices and clashes, he predicted, a united Ireland would result under the benign influence of American republicanism. "Cry Union in America and Liberty in Ireland," Train bellowed. ${ }^{19}$ 
Neutrality and belligerent rights raised questions over empire and foreign relations in unexpected ways throughout the war. Like many Union supporters, Train's Anglophobia was born from frustration with Britain's failure to maintain a strict neutrality. By blessing the Confederacy with the rights of a belligerent power through the Neutrality Proclamation of May I3, I86I, the Palmerston administration brought these issues to the center of debates over Anglo-American relations. Before his audience at the Bunker Hill commemoration, Train challenged the assembled Britons:

Change positions for a moment. Did America hasten to acknowledge the Irish Rebellionists as belligerents, and send a hostile fleet off the Irish shore to encourage the Irish? Suppose the United States had dispatched a squadron to the mouth of the Thames with instructions to await the issue of the rising of the Chartists? Did America assist Papineau in Canada? Do we sympathise with the New Zealanders? ... Did not America share the deepest interest in the success of the British arms in India? Did not our people put the flags at half-mast throughout the land when the death of Havelock fell like a knell upon the nations? ${ }^{20}$

The reciprocal duty of neutrality in Anglo-American relations was perhaps Train's strongest argument and placed him in the mainstream of Union opinion. But, by the end of the war, and once back on American soil, Train used the issue to stoke Irish-American nationalism further. "All that I ask now," he told the Fenian Congress in Philadelphia, "is that America shall acknowledge Ireland as a belligerent." 21 "It is our duty, as England has done so much for our blacks to do something for her whites," Train continued. According to Train, living conditions in Ireland were "below the level of our lately enslaved negroes." 22 Like many Young Americans overseas, Train made little distinction between nationalist aspirations and the United States' global interests.

However limited Train's ideas appear, his emphasis on national selfdetermination, the strict application of international legal norms, and racial proscriptions placed him in dialogue with many of the leading intellectual currents of the mid-nineteenth century. Before the war, Train drew from popular currents of mid-century Anglo-Saxonism and predicted that "the two great branches of the Anglo-Saxon race" would cooperate "under the flag of our own happy land and the strong arm of England." ${ }^{23}$ In another summary of the war's meaning, Train argued that it was "working out a new destiny for our western civilization," and that "humanity" had "gone to America to pass its manhoood." 24 The Bostonian therefore exported a vision of the United States in which 


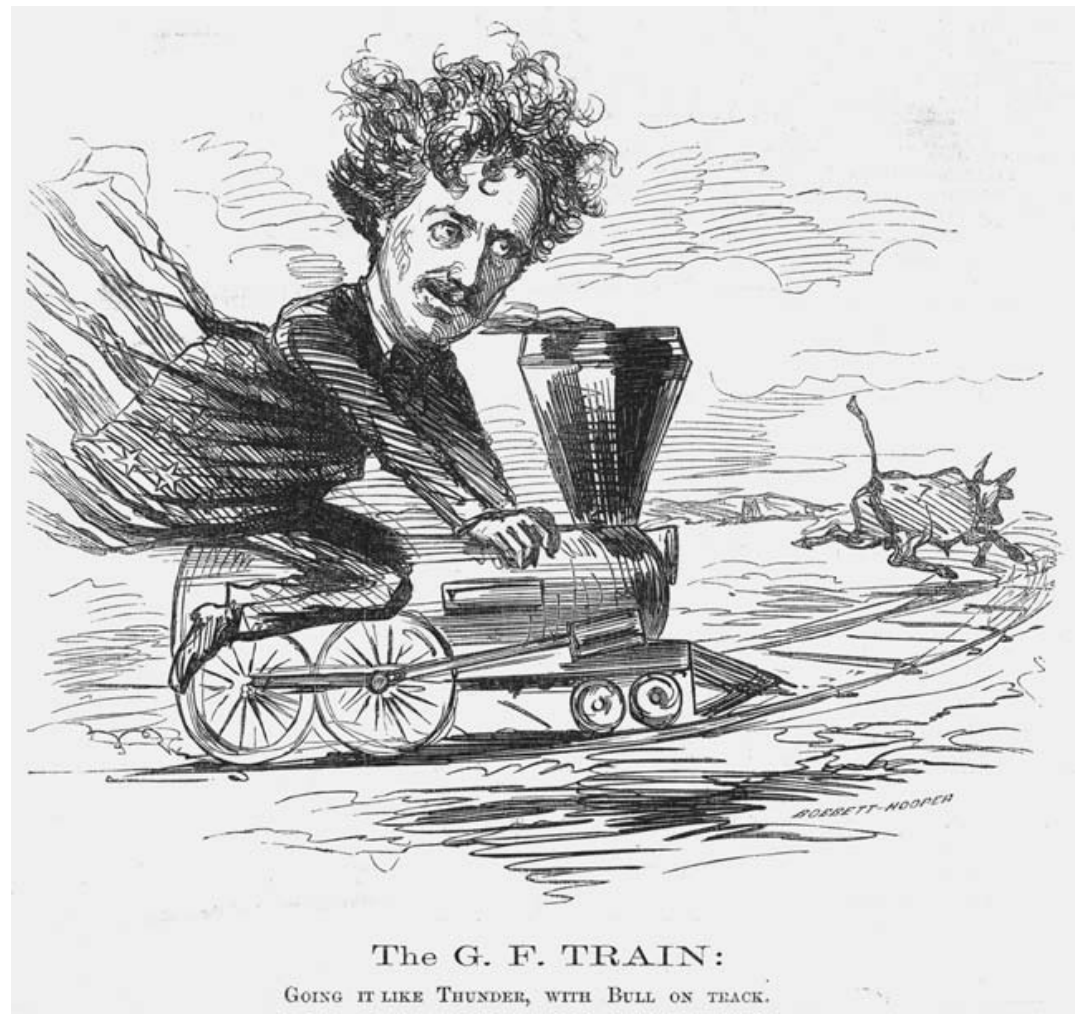

FIGURE I 5. Train's dramatic personality and speaking style were the source of much curiosity and amusement to contemporary observers. The Bostonian was parodied as George Augustus Strain, "the self-elected representative of Yankeedoodledom," in one pamphlet circulating London in June I86I that attacked Train as "as the bould [sic] advocate of secession and negro bondage" (Anon., Bunkum Hill Festival [I86I], 2). The pamphlet is anonymously written but is in the collection of emigrant book dealer Henry Stevens (Folder 29, Henry Stevens Family Correspondence, VHS). Though it was at times impossible to balance his contradictory motives, Train's persistent lecturing lent some urgency to the Union's cause in the war's early months and placed the question of neutrality before the British public in dramatic fashion. Image: "The G. F. Train: Going it like thunder, with bull on track," Vanity Fair, July 26, I 862, Lin 2906.5, Houghton Library, Harvard University.

its racial origins, liberalism, and contribution to the ongoing processes of civilization would confer international legitimacy on its democraticrepublican nationhood. But his emphasis on cooperative empire anticipated the Anglo-American racialism of the late nineteenth century. Seen in this light, Train's hope "to cement forever the union of England and America" appears prescient..$^{25}$ Thirty-five years after the US Civil War, 
elements of his vision of a reciprocal Anglo-American empire would flourish in the American "colony" in London (see chapter 5).

Train cut an eccentric figure in London (captured in figure I 5). In some circles, Train was known as the "Yankee Bull in an English China Shop." Train's eccentricities frustrated most Americans in Britain, however. According to Benjamin Moran, Train was "a complete charlatan" and a "mad dog." 26 "Mr. Train speaks, or rather raves, once a week in some public room," wrote the Saturday Review, "and one of the functions of the London American is to report the violent absurdities of which he thus delivers himself." 27

Nevertheless, Secretary of State William Henry Seward viewed the American as a worthwhile enterprise and contributed \$ Ioo to the publication in I 862 to help it become a "permanent thing in England." 28 Train left England in early I 863, shortly after his arrest for inciting Irish revolutionaries. The American was left in the hands of his secretary George P. Bemis, but soon folded. Train and the American's successes were mixed. While the American became the focal point for Union agitation in the opening years of the war, agents of public diplomacy were most effective when they exploited the intersection of Britain's American emigrant community with British high society-as the case of the London Branch of the United States Sanitary Commission highlights. More revealing is Train's intersection with the discourse of race in Confederate diplomacy. When contrasting the imperial-monarchical rule of Britain over Ireland, Train stoked Fenian grievances and played on popular racial prejudices by declaring that in the United States "five negroes are allowed three votes by the Constitution, which makes a negro threefifths of a man; but in England he is not counted so high as the cattle of the field or the trees in the forest." ${ }^{29}$ This was no mere rhetoric: Train cultivated intellectual connections with European and American racial theorists and viewed civilization and white republican rule as synonymous. In so doing, Train implicated himself in the crosscurrents of the Confederacy's voice in Europe, The Index.

Henry Hotze's propaganda paper was the centerpiece of a major Confederate publishing arm in Britain that commissioned and financed the publication and circulation of pro-Southern publications and intelligence. ${ }^{30}$ Once established the paper secured correspondents in Dublin, Frankfurt, Berlin, Versailles, Paris, Turin, and even Australia, in addition to New Orleans, Norfolk, New York, and Hartford (CT), eventually achieving a modest estimated circulation of $2,500 .{ }^{31}$ Its editorial pages, all penned by Hotze, lobbied for the recognition of Southern independence 
and hoped to "delve deeply" into "the rich mines of British thought" and bring the South "back to a closer intellectual communion with the parent source of their language and literature." ${ }^{32}$ The Index set forth the intellectual case for recognition based on the Confederacy's right to selfdetermination and commitment to free trade. Hotze invoked the ethnicity of Southern nationhood, emphasizing the heroism of Confederate soldiers and their leaders in contrast to the tyrannous rule of the North over the South. "It is impossible to enslave eight millions of people who prefer ruin and death to national dishonour," Hotze wrote in a typical editorial, adding that "the independence of the South will break down a monopoly that impoverishes the world. Posterity will wonder at the apathy with which nations conscious of the advantage of free trade beheld the contest." ${ }^{33}$

The power of Hotze's argument was not solely in its appeal to the framework of romantic nationalism but in its blending of King Cotton's political economy with an expansive vision of the South's place at the heart of the nineteenth century global economy. In Hotze's vision, free trade, cotton, and vast agrarian resources would bring stability and prosperity to the Anglo-Southern dominance of the global marketplace. ${ }^{34}$ Hotze invoked British economic self-interest in terms that would appeal to an incipient imperial economy. "The independence of the South, opening to unrestricted free trade a market of fabulous capacity for production and consumption," he argued in June I 862, "would be equal to the discovery of another India." ${ }^{35}$ Hotze tenuously claimed that "the Southerners were the first people in modern times to advocate the principle of Free Trade" but had "been kept from putting their favourite theory into practice for years by the legislative aggression of the North." ${ }^{36}$ Hotze made the argument most succinctly, and ill-advisedly, when he wrote of the Southern economy: "they produce all that England consumes, they consume all that England produces." ${ }^{37}$ Other Confederate propagandists echoed Hotze's view of the interdependence of the British and Confederate economies. In The South Vindicated, Hotze's collaborator James Williams pointedly argued that Southern planters were "the overseer[s] for Great Britain, while Great Britain is but the factor of the planter." 38

Founded as the effects of the cotton famine took hold in British textile districts, The Index's core argument was that the partnership between transatlantic free trade and Southern cotton would cement African slavery's centrality to the world's economic system. ${ }^{39}$ Hotze dismissed the attempts of the Manchester-based Cotton Supply Association and its supporters, such as the industrialist Thomas Clegg, to gain supplies of cotton from India and the Empire as "chimerical," goaded Britons over 
the economic failure of West Indian emancipation, and taunted that the Union viewed "the Union Jack as a paltry rag." 40 Such a strategy was almost rewarded in the summer of I862, when Robert E. Lee pushed George McClellan's Army of the Potomac out of Virginia and staked the Confederacy's military claim for independence. As news of McClellan's retreat from the Peninsula filtered across the Atlantic, Hotze took advantage of a growing British sense that the North was incapable of overcoming Southern armies and argued that Britain's "listless scepticism" over Southern recognition had brought "the wolf" to Lancashire's door as the supply of cotton dwindled. Not to recognize the South threw it open to the "success of England's most dangerous rival and bitterest foe," and the new master of American cotton would be the Morrill Tariff. ${ }^{41}$

Hotze's faith in cotton's power continued throughout the war. In a December I 863 editorial, the propagandist warned that "jubilations" over the end of Lancashire's cotton famine were "altogether premature." The famine, Hotze wrote, had exposed the vulnerabilities of Britain's textile industry such that spinners were "as willing to depend on charity as to accept the scantily remunerated work which is all that can now be offered them." ${ }^{42}$ Similarly, Hotze collaborated in the publication of George McHenry's The Cotton Trade (I863), which he praised as a volume that "does not beat about the bush." 43 In McHenry's analysis, even if Britain succeeded in developing India's cotton industries, the Colonial Office would only reinforce the importance of the Southern states' commercial dynamo. "As the vast sums of money now flowing back to India develops the resources of that country under the careful management of the British race," McHenry postulated, "the demand for English manufactured goods will greatly augment, and furnish occupation for the increased slave-labour of the South." ${ }^{4}$

Confederate propagandists framed Southern economics in worldhistorical terms. "What is the genius of modern civilization?" The Index's editor asked subscribers in June I862, before answering that "commerce is the chosen apostle of Christianity and civilization." The South was the economic engine of civilization, wrote Hotze, and supplied the world with slave-produced cotton, sugar, tea, coffee, and tobacco. "Do away with them," he wrote, "and the world must return to the status of the sixteenth century." ${ }^{45}$ The North's campaign against the South, he later warned, "aims at converting into a barren waste one of the most fertile and productive regions of the inhabited globe." ${ }^{46}$ In the slaveholder's view of the mid-nineteenth-century global economy, to borrow Matthew Karp's phrasing, "slavery and progress had proved impressively congruent." ${ }^{\prime 7}$ 
With British intervention still a slim possibility in May I862, Hotze placed the South in a transatlantic racial context that celebrated its "closer affinity of blood to the British parent stock, than the North, with its mongrel compound of all the surplus population of the world." Maintaining a revealing silence about Anglo-American imperial rivalry in Central and South America, Hotze argued that Britain and the Confederate states were "natural allies and best friends" bound by "mutual interests" of descent, manners, and commerce. While the South was Britain's "natural offspring," according to The Index, the North was "if not as a bastard, at least a relative of doubtful legitimacy." 48

Southern elites invoked transatlantic cultural connections in a bid to redefine the South's relationship to the wider world in the face of challenges from the unfolding process of global emancipation and nationbuilding. Far from being isolated and parochial, planter-politicians conceived of themselves as members of a cosmopolitan, hemispheric planter class that, united with slaveholders in the Caribbean and Latin America, possessed an acute awareness of global affairs. Alert to the countercurrents in British thought over the success of emancipation in the West Indies, Hotze promoted this vision vigorously, and in one typical passage warned that the South risked becoming "a Jamaica on a larger scale." ${ }^{49}$ In the aftermath of British emancipation new forms of colonial labor management emerged around the Empire that encouraged slaveholding elites in the belief that they could protect slavery in the Americas. Yet, like Southern planters, Hotze could not demonstrate the centrality of the Southern economy to global affairs with enough power to overcome skepticism that the fate of the British economy was entwined with the fate of slavery in the South.

Confederate commissioners found early in the war that the South's appeal would be limited in a nation exposed to a wealth of knowledge on Southern slavery. ${ }^{50}$ Early vexation with British abolitionism found expression through the flexible framework of American Anglophobia, as some Southern apologists in Britain, frustrated by the failure of recognition, harangued the hypocrisy of the British anti-slavery state. "For nearly every drop of blood which flows through the veins of the slaves of the United States," charged James Williams of Kentucky, "our mother England has received the price in gold!" ${ }^{51}$ Southern writers had a point when they highlighted the many degrees of "unfreedom" that existed in the British Empire. In histories of slavery and abolition from a north Atlantic perspective, the 1833 Emancipation Act is rightly viewed as a watershed moment. But as one historian has recently 
pointed out, the chronology of emancipation across the Empire was far from uniform..$^{52}$ The Indian Empire, for instance, was exempt from the I833 Act, and slave trading was not abolished in the region until I 843-slave owning not until I 862. Around the Empire, various forms of apprenticeship, transportation, and penal servitude both predated and outlasted Atlantic slavery and proved enduring means of satisfying colonial labor needs across the globe. In fact, this was made entirely possible because British foreign policy prioritized the battle to end the international slave trade rather than promoting foreign emancipation as the most effective method of achieving its objective of ending slavery. ${ }^{53}$

African American activists engaged directly in this debate. But they looked forward instead to an Atlantic world in which free cotton and free labor were the guiding principles of political economy, arguing that both could be advanced by harnessing the Colonial Office's use of abolition to advance its imperial objectives. The search for a solution to this problem led them toward advocating an alliance between abolition, emigration, and the exact "cotton lobby" Hotze hoped to entice with promises of free trade. Before the war, John Sella Martin had declared that emigration and cotton cultivation overseas was "one of the best means to break a link that binds England to this country with such subserviency that she cringes before the great 'Cotton King." " ${ }^{44}$ At a celebration of West Indian emancipation organized by the Leeds Young Men's Anti-Slavery Society in August I86I, William Howard Day encouraged fugitive slaves to avail themselves of the opportunity to migrate to West Africa where they might "produce a supply of cotton to set off against the American slave-grown cotton," which would collapse cotton prices and "strike a fatal blow at the existence of slavery." ${ }^{55}$ At another meeting in Birmingham, Day combatively argued that the cotton famine was the "direct consequence of disregard by the Anglo-Saxon races of the rights of the African" but, "with God's truth in one hand, and political economy in the other," African American emigrants could elevate "their brother black men." 56 In July i 860 Day, Martin Delany, Robert Campbell, Henry Highland Garnett, and William Craft (also active in the free produce movement) founded the African Aid Society and throughout the war, promoted free black settlement and cotton cultivation of the Niger Valley. ${ }^{57}$ Though highly contentious, these projects were not simplistic counterparts to white imperialism, but a continuation of debates among the free black community over emigration's ambivalent relationship to black Atlantic political identity and anticolonialism and how cotton colonization schemes might further bolster Britain's support for black liberation. 
By I 863 there could no longer be any doubt that the British public was hostile toward Southern slavery. "The longer I remain in Europe," Hotze reflected from Saville Row, "the more I become impressed how extremely difficult and delicate the treatment of the subject of slavery is." ${ }^{58}$ After the release of the Emancipation Proclamation on January I, I863, The Index's editorials descended into full-blooded scientific racialism. In spite of some hostility to Lincoln's message in the British press, notably in the pages of Punch and the Times, Hotze proceeded with caution, stoking white self-interest with appeals to the benevolence of Southern slavery. ${ }^{59}$ "Who would disregard divine and human laws in the blindness of fanaticism which does evil that good may come of it," asked Hotze shortly after the Emancipation Proclamation; "who would set the interest of four million blacks above those of eight million whites, of humanity at large, and of civilization?" He repeated the credo of Southern pro-slave ideologues who contended that slavery was racial philanthropy, arguing that "the hand can not [sic] surely have been an unfriendly one which has thus raised the negro from the turpitudes of the African savage." ${ }^{60}$

The Index placed slavery within an allegedly impartial scientific framework of social hierarchy throughout the world. Slavery was another genus of such English patterns as class hierarchy or the historical subordination of women. Both instances, said Hotze, proved that "intellectual inferiority, and consequently physical, political, and social subordination, are not incompatible with happiness, which does not consist in equality, but in each one performing the part adapted to his or her capacity." 61 Nonetheless, as the Confederate cause drew criticism for its support of slavery, Hotze intensified his paternal rhetoric. "The danger, if danger there is," he wrote, "is the negro's not the white man." "Vilified" and "slandered" by "both honest and dishonest fanaticism," slavery as an institution was undermined, and with it, the security of the enslaved: "The white man everywhere can prosper without it; it is as yet an unsolved problem whether the black man can." Assailed by this fit of fanaticism, the South would be excused from, "the African blood already shed and to be shed in this war." ${ }^{2}$

Hotze, like Baylor before him, moved in currents of international scientific racialism. As Robert Bonner has argued, Hotze forged AngloAmerican intellectual connections that anticipated the racial consensus of late nineteenth century empire-building. ${ }^{63} \mathrm{He}$ cooperated in the establishment of the Anthropological Society in London, an association devoted to the discussion of empire, slavery, and missionary work in Africa and Asia. ${ }^{64}$ The Society's work was advertised through the pages 
of The Index, lending the sanction of the Confederacy by inference. Well-known Confederates George McHenry and Albert Taylor Bledsoe sat on the Society's committee. The former, son of the emigrant Confederate George McHenry, resident in London, was funded by Hotze to the tune of $£_{300}$ in 1864 , far more than was supplied to any other individual. ${ }^{65}$ (McHenry's uncle James also resided in London, sided with the Union, and was a close friend of Benjamin Moran.)

McHenry launched scathing attacks on the abolitionist movement as a "blood-thirsty party" and made an impassioned defense of white supremacy over Southern slaves, who were, he fancifully claimed, "the happiest race on the face of the globe." ${ }^{66}$ "History proves that the natural condition of the black race is one of servitude in its very worst form," he wrote in his most successful Civil War work, The African Race in America (I 862). ${ }^{67}$ In The African Race and The Cotton Trade in America (I 863), McHenry's views on race and slavery were shaped by transatlantic scientific racism. Like Hotze, McHenry drew strongly from the American school of ethnology, and particularly upon the celebrated work of American ethnographer Samuel George Morton and the long lineage of European racial theorists connected to him that included Franz Joseph Gall, Georges Cuvier, John-Joseph Virey, and Johann Caspar Spurzheim. ${ }^{68}$

Together, McHenry and Hotze intervened in a British imperial debate over the capacities of non-white laborers within the Empire. Hungry for cheap labor, successive British governments were apparently satisfied with various forms of "free" bonded labor regimes and were confident that they did not compromise popular understandings of anti-slavery ${ }^{69}$ Within that discussion, some Britons looked to the Southern states as a laboratory for testing whether African-American racial characteristics were fixed, or if slavery had conditioned so-called racial traits. ${ }^{70} \mathrm{McHenry}$ and Hotze assured their British readers it was the former. "The Negro's unfitness for civilization," wrote Hotze in November I863, had been predetermined, and it was "only by observation and experiment that we can determine the exact place in nature which the Negro race should hold." ${ }^{71}$ Hotze and like-minded Confederate polemicists therefore linked the Confederate cause to the new race sciences gaining momentum in Victorian Britain in an attempt to direct attention "away from bondage to the shared Anglo-American commitment to white supremacy."72

Popular phrenological circuits also connected Hotze and McHenry to George Francis Train. Train deplored the "negromania” of Exeter Hall and its "negropolists." 73 Hotze, the overseas apostle of "American School" racial theory, similarly hoped to correct "the heresies that have 
gained currency in science and politics-of the equality of the races of man." 74 In a speech redolent of these themes, Train told one British audience in March I862 that "American slavery is a stepping-stone to the negro from African barbarism to Christian Civilization."75 "In America," he continued, "the Caucasian race has elevated his [the negro's] intellect, as it has improved his physique." But, Train conceded, the "civilized man" could improve them "only as far as he can," for to go further, "you must first put inside his thick skull nine cubic inches more of brain!"76 Train arrived at his crude phrenology by way of the religious sanction of slavery in Leviticus 25 and Exodus $2 \mathrm{I}$ and the phrenologist Samuel Roberts Wells, editor of the popular American Phrenological Journal, who attended his first pro-Union rally in London on I9 June $1861 .^{77}$ The second major influence on Train was James McHenry, who introduced him to the phrenologists Frederick Bridges; Cornelius Donovan, founder of the London Phrenological Society; and Orson Squire Fowler of New York.

Hotze and Train alike sustained the connection between international politics and scientific racialism. Hotze failed to link this successfully to Confederate recognition, and later complained to Judah P. Benjamin that Confederate failure was grounded in the inability of Europeans to appreciate the "unsolved and unprecedented problems involved in the management and education of the African race." ${ }^{78}$ It was through the avenue of informal diplomacy that transnational intellectual connections were forged between western racial theorists, who in turn cemented the international legitimacy of racial hierarchy in the post-Civil War decades. ${ }^{79}$ The decline of slavery coincided with the expansion of empire and new dilemmas for sustaining white rule. The racial consensus emphasized by these ideologues was encoded over the next half century in new Anglo-American imperial formations. Informal diplomats and overseas agents offer an opportunity for historians of American foreign relations not simply to "thicken" the Civil War's global context, but, through their discussions of racial capacity, connect the war to the century-long challenge of governing and maintaining multiracial imperial projects in Britain and the United States. ${ }^{80}$

\section{THE DIPLOMACY OF HUMANITARIANISM}

The Civil War reinvigorated Anglo-American humanitarian movements, as thousands of American men and women volunteered to contribute to wartime relief efforts-fertile ground into which new move- 
ments advanced their cause. ${ }^{81}$ Patriotic and Christian impulses were institutionalized in June I86I in the form of the United States Sanitary Commission (USSC), which worked alongside the War Department to organize field hospitals, train nurses, and treat the sick and wounded. ${ }^{82}$ The transnational circulation of humanitarian activists and the emergence of new networks of sanitary reform between scientific elites in American and European cities were equally important to the activities of the USSC—as were the philanthropic and diplomatic energies of American emigrants in Britain. ${ }^{83}$

The transatlantic celebrity of Florence Nightingale and the popularity of her I 863 volume Notes on Hospitals fueled the interest of American philanthropists in battlefield sanitation, while the British Sanitary Commission of the Crimean War provided the model for the organization of USSC hospitals. ${ }^{84}$ The USSC drew heavily from the work of English sanitarians who recommended the disposal of waste, the necessity of ventilated wards, and rapid transportation from battlefield to hospital bed. ${ }^{85}$ Such transformations also depended upon the transnational dissemination of information regarding health and disease to train nurses, educate army surgeons, and efficiently organize relief infrastructure. The USSC's scientific philanthropy, then, drew from an international context in which issues of public health, sanitation, and humanitarianism were being examined by new, non-state associations that emphasized the collection and study of data and collaboration with the state. ${ }^{86}$

These transnational currents of scientific philanthropy also increased the international footprint of the USSC itself, with the founding of two overseas branches in $\mathrm{I} 864$. The origins of this international mission were in Paris. Prompted by a "wave of patriotic devotion" that had "rolled across the Atlantic," a coalition of Americans in the City of Love were corralled by Charles S. P. Bowles and his brother William B. Bowles, senior partners of the international financiers Bowles Brothers, into forming a European branch of the Sanitary Commission. ${ }^{87}$ Bowles collected $\$ \mathrm{I}_{3}, 372.72$ in donations, shipped large amounts of high-grade brandy for medical purposes to Sanitary Commission field hospitals, and forwarded tons of gifts for sale at the New York Sanitary Fair. Bowles was appointed the official USSC Foreign Agent in Europe in the summer of I 864 and was active in the emerging forums of international aid. This mixed approach to relief and agitation would also be adopted by the USSC's London Branch.

This group was founded in a meeting held at the London offices of sewing machine manufacturers Wheeler and Wilson's on February 20, 
I 864, attended by US Consul General Freeman Harlow Morse, Cyrus M. Field, Judge John G. Winter of Georgia, R. Hunting, and Henry Starr of the firm Wheatley, Starr \& Co. ${ }^{88}$ Field provided impetus for the new movement in March with a gift of I,000 tons of coal to be sold at the New York Sanitary Fair. The US Consul in Liverpool, Thomas Haines Dudley, arranged for the American-owned Guion \& Co. (managed by Henry Guion of New York) to ship the coal free of charge..$^{89}$ In March, a second meeting at the London Tavern, this one chaired by William M. Evarts, in London as legal counsel for the Alabama claims, finalized the details of the London Branch's organization, at which the gathered American residents and visitors pledged to "make a combined effort to swell the contributions in aid" of the USSC's efforts. ${ }^{90}$ Under guidance from the Commission's President Henry Bellows, the London Branch was conceived as a mission "to convince Englishmen of the strength of democratic or popular institutions" undergoing a "terrible trial" and to "prove" that the "republican bubble had not burst." 91

As with Union foreign relations more broadly, the London Branch mobilized the financial, philanthropic, and social networks laid by the previous decade of organization among American society in London. Peabody and Co., Barings, and Brown, Shipley were nominated as its banks of deposit. Goods would be shipped from London by Wheatley, Starr \& Co. and Liverpool by Guion \& Co. free of charge. ${ }^{92}$ Diplomatic and consular agents were mobilized in support of the Branch. Benjamin Moran, Benjamin Nunn, Charles Lush Wilson, and Freeman Harlow Morse in London, and Thomas Dudley in Liverpool, distributed pamphlets on behalf of the USSC and coordinated the transport of gifts. Its executive and subscription committees were drawn from the diverse character of London-America, but its most high-profile members were those with the greatest social standing. These migrants were integral to the London Branch's success, as they granted access to elite social circles as well as the knowledge they possessed of Union supporters in Britain. At the second meeting, these transatlantic figureheads were appointed to senior positions in the Branch's organizing committee.

If prominent Americans in Britain provided social capital, Edmund Crisp Fisher, an otherwise obscure Illinoisan, provided the momentum. Described by Moran as “a reliable man," Fisher's tenure as secretary was both energetic and entrepreneurial. ${ }^{93}$ Through his efforts, the London Branch become both a conduit for donations and gifts from Britain and a far-reaching propaganda arm. From his base in London, Fisher moved quickly and appointed English journalist Frederick Milnes Edge as agent 
in Manchester. Soon after he penned a circular to "All Americans known to be resident in Britain," in which he exhorted them to contribute to the commission's work. Before Britain's American community lay “a duty which we owe to our country in her hour of danger, battle and death;a duty forced upon us by every consideration of humanity;- - a duty to whose imperative calls no reflecting man can turn a deaf ear." ${ }^{94}$

Fisher opened reading rooms at 2I Cockspur Street near Trafalgar Square, opposite the headquarters of the pro-Confederate Southern Association. More importantly, it was a short walk from Morley's Hotel on the Square's eastern side and the Union Hotel on the western side, both popular with American visitors. Described in the press as "a kind of Union and Emancipation Club, where all who believe in civil and religious liberty may meet to read, chat, write, and rest," the rooms acted as the hub of Union philanthropy. ${ }^{95}$ Inside, visitors browsed copies of USSC publications such as the Bulletin and Reporter, examined maps of US battlefields, and consulted a register of Americans resident in London. Moran then persuaded Fisher and Ezekiel Elliott (head of the USSC's Bureau of Vital Statistics, then touring Britain to promote the science of sanitary reform) that it was "of national interest that there is in London [a] headquarters for loyal Americans" to influence "public sentiment in Europe." ${ }^{96}$ Although it was thought inadvisable to actively seek financial contributions from Englishmen, Elliot hoped to "quietly strengthen the hands and voices of our earnest English friends," such as the sanitary reformer Edwin Chadwick and the public health statistician Edwin Lankester. ${ }^{97}$

The USSC London Branch successfully coordinated all the elements of London-American society, in addition to the interwoven philanthropic, anti-slavery, and religious networks in Britain outlined in chapter 3. Fisher's second appeal chided Americans in Britain for their "ungenerous apathy," but addressed a wider audience of sympathetic Britons and "especially churches." Fisher exhorted the members of these diverse networks to support "a work which has placed America in the foremost rank of charity, religion and humanity." ain's churches that Fisher could utilize a shared culture of transatlantic evangelicalism and cultivate a fertile audience for the USSC's interdenominational Christian philanthropy that reached into local communities around Britain. Religious emissaries had cultivated this audience before him, and Fisher attempted to utilize the shared Protestant culture that underlay these diplomatic missions by forwarding pamphlets to British churchmen. 
Transatlantic evangelicalism was just one vein of the vast arterial network of philanthropy, reform, and activism drawn upon by the USSC. Fisher cultivated links with Elihu Burritt, then lecturing in England after the shattering of domestic support for his international peace movement. ${ }^{99}$ Burritt, the self-styled "Learned Blacksmith," was a protégé of the recently deceased English abolitionist Joseph Sturge, whose patronage in the 1840 os gave him the ear of Quaker abolitionists in the Midlands in addition to more than 50,000 men and women who had pledged to support his League of Universal Brotherhood during his I 846 tour across the country. The effervescent John Sella Martin, who sat on the subscriptions committee, provided connections with the African American anti-slavery lecture circuit and grassroots pro-union and abolitionist organizations. Thomas Bailey Potter, President of the Union and Emancipation Society, spread sanitary commission materials among the organization's members. ${ }^{100}$ Through this constituency Fisher prepared the ground for the Sanitary Commission's message of Christian philanthropy at a politically sensitive moment.

Sensing that the public mood was shifting towards war-weariness by the fall of $\mathrm{i} 864$, Fisher flooded Britain with USSC pamphlets to emphasize the compassion of the Union war effort. "I am pegging away at English ignorance and prejudice," Fisher wrote to Bellows in December I 864. ${ }^{101}$ Between October I 864 and April I 865 , Fisher circulated USSC publications to high-profile members of British society including the Prince of Wales, Lord Granville, and George Grey; local and university libraries; and civil society organizations including the Society of Manufactures and Commerce, and the Athenaeum. Fisher also cultivated British military establishments including the Admiralty, the Royal Artillery Library, the Army Medical Library, and the Colonial Office. Nonetheless, he found the English "slow to move, and hard to convince." Writing to Jenkins in New York, he argued that "they have for so long a period been educated to believe that no good could come out of an 'American Nazareth." But he remained optimistic that through the Branch's auspices "a vast amount of ignorance and prejudice have been removed, and the American character is its best and noblest aspect." 102

Judging the success of such advocacy missions is almost impossible, but Fisher certainly increased the profile of the Sanitary Commission among the British public. Some sense of the scale of this effort can be gauged from the frequent delivery of new materials to Fisher from New York. Jonathan Woods, a clerk in the New York office's Document Bureau, forwarded large packages of Sanitary Commission pamphlets to 
London and Paris. In September I 864 Woods sent Fisher two hundred copies of the Commission's fortnightly Bulletin and maps of Andersonville Prison. ${ }^{103}$ As new pamphlets emerged, Fisher capitalized on their propaganda potential. In early I 865 he obtained hundreds of copies of Robert McKenzie's America and her Armies and forwarded them to newspaper editors, bankers, cabinet members, and bishops. Soon the flow became a flood. In February i 865, Dudley received thirty thousand copies of the Sanitary Commission Reporter. ${ }^{104}$ One month later, Woods sent Fisher copies of the Narrative of Suffering, medical and surgical monographs, complete sets of the Reporter and Bulletin, financial reports, Katharine Prescott Wormeley's Sketch, the Commission's Narrative of its Works and Purposes, and the Memorial of the Philadelphia Fair. ${ }^{105}$ Using US consuls as local distributors, Fisher engaged grassroots Union organizations, philanthropic associations, and interested local elites.

The English Branch also helped to organize events for Sanitary Commission agents. When Ezekiel B. Elliott visited London to attend a meeting of the Society for the Promotion of Social Science in I864, Fisher arranged a speaking tour to specialists interested in the physiognomy and mortality of the Union Army. ${ }^{106}$ Fisher himself also lectured to select groups of scientists and military officers. In late I 864, he delivered his lecture "Military Discipline and Volunteer Philanthropy" to the first Social Science Congress in the northern city of York. He was next invited to speak before the Royal United Service Institute, a defense academy dedicated to the study of naval and military science. Following the tour he distributed a pamphlet version of the lecture to "leading Englishmen" at British universities and scientific and military institutions. ${ }^{107}$ Fisher portrayed the Commission to the British public as a volunteer regiment of the Federal Army and described its work as "absolutely Samaritan," while simultaneously being the "power maneuvering the lever" of the Federal Army. ${ }^{108}$

The timing of the London Branch's public campaign was prescient. "I eschew carefully all political discussion," Fisher somewhat disingenuously informed Jenkins in New York, when in fact he was the mastermind of a well-organized counterattack on Confederate propaganda. ${ }^{109}$ In hopes of reigniting the recognition debate, Hotze's Index began reprinting articles from the Richmond Examiner detailing the "barbarous treatment" of prisoners of war and placing the blame for the end of prisoner exchanges at the door of Union officials. ${ }^{110}$ After an outburst of pro-Union support following the Emancipation Proclamation, Britons were becoming increasingly frustrated by the war's cost in human life (see figure I6). Confederate 


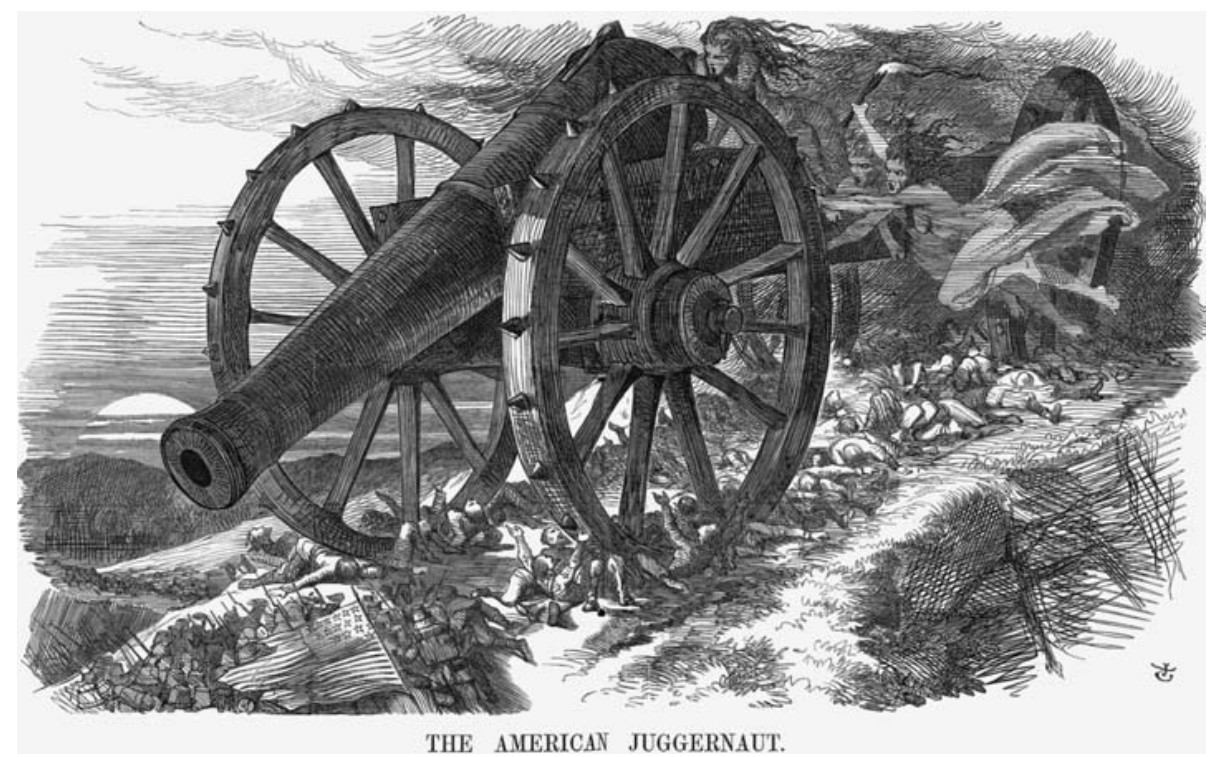

FIGURE I 6. Here the Punch artist John Tenniel portrays the horrors of mechanized warfare. The war's terrible cost in human life, the apparent inability of either side to inflict a knockout blow, and the news of starvation among the civilian population and the mistreatment of prisoners by both sides prompted humanitarian concerns in the British press. This reality was brought home most shockingly in the illustrations of Tenniel and the Illustrated London News artist Frank Vizetelly. Image: “The American Juggernaut,” Punch, September 3, I864, The Cartoon Collector / Heritage-Images / TopFoto.

propagandists in Britain attempted to channel this frustration towards a new petition campaign among pro-Confederates that now centered on the inhumane length of the war rather than direct recognition after the failure of Roebuck's motion in 1863.111 The route to recognition, many proSouthern ideologues now believed, lay in appealing to British humanitarian sentiment to force an armistice. ${ }^{112}$

To fan the flames further, James Spence, recently relieved of his position as the Confederate States' financial agent in Europe, organized a four-day "Southern Bazaar" for Liverpool's pro-Confederates in October. Ironically, Spence hoped to capitalize on the same humanitarian impulses as the USSC, by exciting "sympathy for the great sorrows and suffering that now afflict a people of our own race" to force a negotiated peace. ${ }^{113}$ "Public opinion has quite come round to the belief that the North is staggering under its last efforts," Spence wrote Mason. ${ }^{114}$ More than ten thousand British sympathizers visited the Bazaar at Liv- 
erpool's St George's Hall, decorated with Confederate flags and portraits of Stonewall Jackson, to see such attractions as Robert E. Lee's pipe and crosses made from the wreckage of Fort Sumter. ${ }^{115}$ A roaring success, the event was extended to a fifth day, and Spence's final profits totaled more than $£_{I 7,000}$ (more than $£_{2}$ million today) in aid of the Southern Prisoner's Relief Fund. ${ }^{116}$

The Bazaar was, however, the last stand of the retreating Southern cause in Britain. Spence, Hotze, and their supporters had failed to create a viable pro-Southern coalition and were forced onto rapidly shrinking ground by the success of British abolitionist societies in winning support for the North. Writing under pseudonyms in the British press, Fisher countered Confederate claims of Union mistreatment and emphasized the Christian rather than sectional character of the Sanitary Commission. Fisher dismissed the Bazaar's organizers as "sundry aristocrats and fashionables" and appealed to British patriotism by depicting the USSC as "borrowing much from the saint-like labors" of Florence Nightingale and laboring "on purely philanthropic grounds-helping alike both friend and foe, rebel and loyalist, and looking only to suffering humanity." Finally he called on Unionists in Britain to "eclipse this Southern and sectional bazaar" and "to repel the insidious efforts" of Spence to substitute the republic for a "slave empire in the nineteenth century of the Christian era." ${ }^{117}$

Fisher did not have to press this point very hard. The Confederate Bazaar raised impressive amounts of money, but paled in comparison to the work of Fisher and allied campaigns such as the Freedmen's Aid movement. Following the Emancipation Proclamation approximately fifty societies were founded in Britain, many at the initiative of women, to provide material and financial aid to freed slaves. ${ }^{118}$ These local groups, coordinated through the National Committee of British Freed-Men's Aid Societies, shipped clothing, tools, and cash to refugee camps in the South. ${ }^{119}$ They were joined by the agents of American societies, including Quaker abolitionist Levi Coffin and D.A.M. Storrs on behalf of the Freedmen's Aid Society, Robert J. Parvin for the American Freedmen's and Union Commission, Charles C. Leigh for the National Freedmen's Relief Association of America, Dudley Haynes, who lectured on behalf of the London-based Freedmen's Aid Society, and once again John Sella Martin, who acted as agent for the American Missionary Association, having been sent to "use my old connections here." ${ }^{120}$ Martin lectured British audiences with a "holy indignation" and appealed to British ideals of self-help to request aid for preparing the newly-emancipated slaves for 
freedom. "The negroes distrusted their own powers," he told an audience of Glaswegians in August I 865, "because they had never been called on to exercise them as independent men." Slaveholders would not "yield their grasp upon the neck of their victims without a great struggle," but the now-former slaves could be prepared for the struggle if "the people of this country could make the negro believe that all their avowed interest and oft-repeated protests against the evils of slavery, and oppression were earnest and real." ${ }^{121}$ Between I 863 and I 868 an estimated $£_{\mathrm{I} 20,000}$ in financial aid and $£_{20}, 000$ of goods were donated by the British societies to this end (more than $£_{13} .5$ million and almost $£_{2} .3$ million today respectively). ${ }^{122}$ Coffin alone raised a further $\$$ I OO, 000 in money and gifts in Britain. ${ }^{123}$

British humanitarians thus provided Fisher with a broad movement, knowledgeable about the American crisis and its consequences, through which to advance the USSC's cause. Fisher pressed Confederate inhumanity on the British public by circulating the Sanitary Commission's Narrative of Privations and Sufferings (I 864) to members of the Palmerton cabinet, philanthropists, and British elites. ${ }^{124}$ Dudley and Fisher collaborated to distribute tens of thousands of copies. According to the Liverpool consul it was "beyond question the best book to circulate in this country that has been sent to us." 125 "You can't reach the English mind with argument," Dudley wrote Fisher, "they can only be moved by acts like these of cruelty, surpassing anything that has been practiced in this age and only finding counterparts in the dark ages of the world." 126 "The distribution of the Narrative of Suffering [sic] has come at a very good time," Fisher wrote to the USSC General Secretary, J. Foster Jenkins, "for the public mind has of late been especially drawn to the so called sufferings of Rebel Prisoners." 127

In February I 865 alone, Dudley was sent and distributed fifty-five thousand copies of the Narrative around Britain. ${ }^{128}$ Fisher forwarded copies to every member of the Houses of Lords and Commons, the Cabinet, and to all members of the UES. ${ }^{129}$ Driven by the increasing momentum of the Commission's cause, Fisher drew on his contacts in evangelical and philanthropic networks. ${ }^{130}$ Fisher's campaign consolidated the PR effect of Sherman's occupation of Savannah in December I 864 and the fall of Fort Fisher in January I 865 , which, combined with the Narrative's report of Confederate cruelty, helped to bolster the perception of the Union's moral purpose to British observers. ${ }^{131}$

USSC pamphlets joined a flood of works about the war from grassroots union organizations, middle class intellectuals, and upper class 
reactionaries-not to mention the constant coverage in British national and local newspapers. Fisher's efforts were not simply another voice in the chorus, however. USSC literature universalized the conflict's meaning and emphasized the humanity inherent in the Union military campaign despite its tremendous human cost. Fisher exploited the war's international audience and never doubted that the USSC's Christian and philanthropic mission could act as a transnational pressure point on British public opinion. Reflecting on the Branch's purpose after the war, Fisher concluded that it had been "a missionary" and a "schoolmaster" that had instilled "into the minds of Englishmen the lessons of our struggle." ${ }^{132}$ How far it shaped or transformed English opinions on the war is, of course, impossible to say, but in raising the profile of the Sanitary Commission Fisher agitated issues that were easily allied with the philanthropic and Christian impulses that fueled much British support for the Union. "The mask has been raised," wrote one of Fisher's correspondents from the British Army, "and the people of all countries where copies of your Treatment of Prisoners are read can see the Southern pall bearers of starvation chuckle their shoulders and curse the moment your association peered into their death like recesses." 133

The London Branch's greatest strength was its ability to build on longstanding networks of Americans in Britain. These networks also provided a steady flow of financial donations to the London Branch's activities. As knowledge of the USSC grew in Britain the London Branch received increasing numbers of donations in cash and kind for sanitary work. "We accept foreign assistance only in the name of a cosmopolitan sympathy," wrote Bellows in his advice to Fisher, adding that it would promote "a common bond among Christians and men, the world over." 134 Rather than rely exclusively on such philanthropy, Fisher was more active in his solicitation of funds from the London-Americans. In his first circular to Americans in Britain, Fisher wrote that although the "tangible monetary aid that we in England can render may be a mere drop in the mighty stream of benevolence," the "God-speed you from a foreign shore" would nonetheless "soothe many an aching brow." 135

Emigrant financiers on the London committee gave generously. The largest donation to the London Branch came at the end of May I864, when George Peabody gave $£ 8$, ०00. That was in addition to the $£ 500$ he had given to fairs in Boston, New York, Philadelphia, and Baltimore, bringing the total to $£_{I 0,000}$. Although it did not quite match the dona-

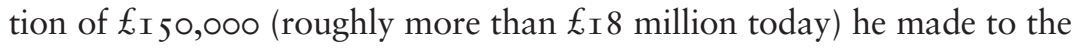
London poor in I 862 (and his subsequent addition of $\$ 2,500,000$ to that 
fund) the I 864 donation was a ringing endorsement of Fisher's enterprise and the Commission's efforts. ${ }^{136}$ In this instance, the ageing Peabody wanted to express his endorsement of "a real Christian charity" and to help "alleviate the pains and give comfort to the sick and wounded of both the northern and southern armies." ${ }^{137}$ Peabody's gifts to the London poor and Sanitary Commission in the war years were part of more than \$Io million given away between I 856 and his death in I 869 to projects on both side of the Atlantic that he hoped would tie the English-speaking peoples closer together. ${ }^{138}$

Despite rumors circulating from the Paris Branch that the "Copperhead element" existed "to no small extent among the prominent Amer-

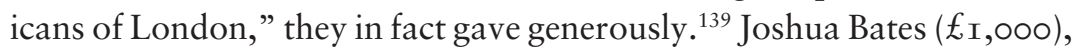
James McHenry $\left(£_{\mathrm{I}, 000}\right)$, Alexander Brown $\left(£_{3} 00\right)$, Russell Sturgis $\left(£_{\mathrm{I}} \mathrm{O}\right)$, and Stewart H. Brown $\left(£_{\mathrm{I}} \mathrm{O}\right)$ provided donations from the financial elites of Britain's American community. Meanwhile, American merchants in Britain added further funds. From Liverpool, the shipping magnate Henry Gair provided not only free transportation for gifts in kind to Sanitary Fairs but donated $£_{\mathrm{I}}, 0 \circ \mathrm{0}$, followed by gifts from Henry Starr ( $£_{39}$ I), Curtis Miranda Lampson ( $\left.£_{250}\right)$, and Stephen Guion and Benjamin F. Babcock ( $£_{\mathrm{I}} \mathrm{O}$ each). Donations from Charles Francis Adams ( $\left.£_{\text {IOO }}\right)$, Charles Lush Wilson $\left(£_{50}\right)$, Freeman Harlow Morse $\left(£_{2} \mathrm{O}\right)$, and Benjamin Moran ( $£_{\mathrm{IO}}$ ) highlight the synergy of the US diplomatic elite in Britain with the Sanitary Commission's mission in Britain. ${ }^{140}$ The London Branch also benefited from the generosity of native Britons, such as the citizens of Cardiff, who gave more than $£ 850$ in April I 863. "I feel I am addressing a fellow countryman," wrote one Glaswegian as he sent a small gift through Thomas Dudley. ${ }^{141}$

Overall, gifts through the London Branch totaled $\$ 36,790.42$ and accounted for more than half of the total donations from Europe, which stood at $\$ 65,976.44$ (more than $\$ 500$ million and $\$$ I billion respectively today). ${ }^{142}$ Financial donations were supported by gifts in kind to Fairs in New York and Chicago. In Britain, Fisher depended on Thomas Dudley to organize the shipment of huge numbers of gifts received in Britain. ${ }^{143}$ Long-standing philanthropic practices in Britain of sending gifts to American anti-slavery bazaars were a good fit for Fisher's model of philanthropy. ${ }^{144}$ Donations came from Britons and Americans alike and included practical items such as tin plates, cutlery, needlework, wool, rifle parts, and iron wire. ${ }^{145}$ But the cases forwarded by Dudley also included luxury items to be sold at fairs in the US, such as perfum- 
ery sent by the railroad promoter James McHenry and oil paintings from former Treasury Secretary Robert J. Walker, in Britain as a special envoy charged with discrediting the Erlanger Loan, an attempt by the Confederacy to raise \$I 5 million of cotton-backed bond sales through the French financial house Emile Erlanger \& Co. ${ }^{146}$

In London, donations to Fisher's branch were not only an expression of support for the Union but an extension of the longstanding civic life of the London-Americans. Americans in the capital demonstrated their connection to the United States through the assumption of extradiplomatic duties such as the disbursement of funds for stranded sailors and travelers, through the founding of newspapers that sought to promote knowledge of the United States, and by taking up the reins of informal lobbying and propagandizing where ministers and consuls could not tread. Fisher's London Branch was so successful because he drew on the interleaved social worlds of commerce, diplomacy, and philanthropy of Britain's American emigrant community.

As evidence of the widening progressive connections between Britain and the United States in the Civil War era, concerned citizens in the United States reached across the Atlantic in aid of Britons suffering through the cotton famine that began in I 862. Leaders of the New York Chamber of Commerce quickly mobilized support for working-class Britons. At a specially called general meeting in November, \$26,000 was raised within minutes. William Earle Dodge, the "Merchant Prince" of New York, donated \$5, 000 ; John Taylor Johnson, a railroad executive and art collector, subscribed \$2,500, as did the Babcock brothers. Alexander T. Stewart, a wealthy New York department store owner, donated \$ I o, ००o for the operatives, while another firm offered to transport I, 800 tons of supplies to Lancashire sufferers. Donations of provisions flooded in from Northern and Western states, including one thousand barrels of flour from the social reformer and abolitionist Gerrit Smith. ${ }^{147}$ In Liverpool, the goods were received by prominent American residents Daniel James, Stephen B. Guion, and Benjamin Franklin Babcock, who distributed them around the affected region in the winter of I 862-63 through local relief committees. ${ }^{148}$ "It is making a good impression all over the country," James reported to the committee. ${ }^{149}$

The International Relief Committee collected more than \$ I20,000 in donations and shipped almost 16,000 barrels of flour, 500 bushels of corn, 375 boxes of bread, 50 cases of pork, and other foodstuffs. ${ }^{150}$ This 
dramatic diplomatic gesture inspired many activists in the British Freedmen's Aid movement and reinforced the transatlantic community of sympathy that underlay emerging connections among international humanitarians. The voluntary, humanitarian diplomacy seen here was reinforced by the international language of Anglo-Saxonism increasingly central to transatlantic relations. The "piteous cry of the starving operatives of the mother country" resonated so strongly amongst New York's merchants, according to the Chamber's official history of the event, since they were “'bone of our bone,' and all endeared to us by a common language, a common literature, and a common origin." ${ }^{151}$ As the Freedmen's-Aid Reporter expressed it after the war, the "wise and generous co-operation" among "transatlantic Christians and philanthropists" was of "incalculable value" in drawing "into closer friendship the spiritual and moral conservatism of the two great branches of the Anglo-Saxon race." 152

Ironically, both Union and Confederate diplomatic strategies reified the perception of this shared transatlantic racial identity. The emphasis on race in Confederate diplomacy intersected with a trajectory of racial science that sits uncomfortably alongside the humanitarian impulses emanating from the Union's propagandizing in Britain. Nonetheless, as the concept of Anglo-Saxonism evolved over the coming decades in the context of rapid British imperial expansion across Africa and in conversation with new scientific racisms, evolutionary biology, and eugenics, those differences were easily reconciled. Anglo-Saxon civilization, as it would be subscribed to in Britain's American community by the close of the nineteenth century, was an identity of whiteness based on the assumption that AngloAmericans were best suited to manage subject, "uncivilized" races in a humane and "scientific" manner. Humanitarianism, colonial governance, and racial science became mutually reinforcing in this imperial context. ${ }^{153}$ Although renewed diplomatic crises would be stoked by the Civil War's immediate aftermath, this ideology was refined in the cockpit of Britain's American community and pressed into the service of a series of American "invasions" of British social and economic life. 